\title{
Pascoli in Progress: The Contents of Box L
}

\section{Anthony Oldcorn}

What was in box L? Miscellaneous manuscript materials pertaining to the making of Myricae. The answer, to the reader anticipating an alphabetical correspondence, is disconcerting, to say the least. How, in such a world, would Ant and Bee ever have found their lost hats? Fortunately, the veteran pascolista is unlikely to be fazed, accustomed as he is to living with bewilderment, doubt, and suspenseful uncertainty. ${ }^{1}$ Moreover, in the present instance, the Pascolian fog is quickly dissipated, our erroneous alliterative expectations undeceived, and the true Roman numerical value of the $\mathrm{L}$ stands revealed, when we learn that, though the bulk of the papers are in box L, an additional forty-seven relevant items are scattered here and there in boxes LI (Primi poemetti), LIV (Poemi conviviali), LVIII (Poesie varie), LXX (Traduzioni, teatro, poesie sparse), LXXI (Poesie ed altro. Quaderni vari), LXXII (Poesie ed altro. Quaderni vari), LXXIII (Poesie ed altro. Quaderni vari), (Poesie ed altro. Quaderni vari), LXXIV (Poesie ed altro. Quaderni vari), LXXVI (Prose sparse ed altro), LXXVIII (Miscellanea. Cose latine ed altro), LXXIX (Miscellanea ed altro), and LXXXII (Carte scolastiche). The source of our information is the introduction to Giuseppe Nava's exemplary critical edition of Pascoli's Myricae. ${ }^{2}$ The Roman-numbered boxes constitute a relatively small part of the voluminous, and until now virtually unexplored, archive of Casa Pascoli at Castelvecchio di Barga in the province of Lucca. Amorously gathered, pored over, sorted, and in a limited way transcribed and published, by the poet's sister, Maria, the high priestess of the Pascoli cult, during the forty-one years by which she survived his death from cancer in 1912, the papers were taken over, upon her own death in 1953, by the Soprintendenza Bibliografica della Toscana. Though there has been a rough classification and division into the boxes mentioned (and within the boxes into Arabic-numbered envelopes), Nava's is the first conscientious and systematic attempt to catalogue and describe in detail the documents and their written contents, as far at least as the Myricae papers go. ${ }^{3}$

Heirs to the rustic "virtues" of frugality and diffidence, the members of the Pascoli household appear, first, never to have QUADERNI d'italianistica Volume II No 2, 1981 
thrown anything away, and second, to have been most vigilant in keeping all but intimates of extremely long standing at a stout arm's length. Beware of poet's widows, said Montale. And, in some cases, of their surviving sisters, he might have added. ${ }^{4}$ For this severe, jealous, wilful, capable, and utterly devoted spinster, puffing on her black Tuscan cigarillo, snipped in two for the sake of economy, must have been a formidable guardian indeed. Small wonder if the collection of documents has remained, for the sixtyodd years that have elapsed since the poet's death, almost as mysterious as it promises, when fully revealed, to be vast. But then, is it not strange that the published work itself, equally vast, of this, the greatest Italian poet since Leopardi, remains no less mysterious and capable of eliciting the most diverse and conflicting critical opinions? Books on Pascoli still usually begin with an echo of Croce's perplexed self-questioning ("Is it a bore? Is it a poet? It's PASCOLI!"), and even a book as learned, perceptive and enlightening as Alfonso Traina's study of Pascoli's Latin tends to assume from the outset an apologetic and defensive stance. ${ }^{5}$

It is as if the poet's own caution were transmitted to his critics. Caution? The word is something of an understatement when applied to Pascoli's approach to publication. So reticent was he, even in the face of the constant encouragement and exhortation, private and public, of such friends as Severino Ferrari and Guido Mazzoni, that he seems, like an extremely reluctant bather, almost to have backed on tiptoe, rather than plunging, into print. His first volume of verse, Myricae, did not achieve the form in which we know it until its fourth edition, published in 1897, when the poet was already forty-one years old! Technically speaking, the first edition of Myricae came out in Livorno six years earlier, in $1891 .^{\circ}$ It is hard, however, to equate the meager dimensions of the Giusti princeps (a mere twenty-two brief lyrics) with the substantial volume of 156 poems which we know today. Moreover, the stimulus to publish came from a purely occasional circumstance the wedding of a close friend. The exiguous commercial edition which brought the total number of copies printed up to $100-$ was an afterthought, dictated in part at least by the same straitened circumstances that led him to offer a couple of dozen poems in the first place, instead of the usual coffee or liqueur service. 7 Ironically, even the pious hope that the proceeds of the sale of the extra copies might cover the costs of printing turned out to be vain. As if to confirm the author in his most negative expectations, many copies went in fact unsold. It would probably be wrong to interpret this public indifference as due to a negative calculus of the book's novelty. Nevertheless, it is true - and a further indication of the 
poet's circumspection - that, of the twenty-two poems in the volume, only one ("Mare") had not previously been published elsewhere. ${ }^{8}$

The slim first edition, however, should not be taken as representative of the poet's total production to date. In addition to the twenty-one we have mentioned, a further thirty-five of the fifty poems added in the second edition had already appeared (prior to 1891) in newspapers, periodicals, "opuscoli per nozze," and other commemorative miscellanies, mostly in the previous decade, but the earliest ("Il maniero" and "Rio Salto") as far back as 1877. Some of them indeed had been printed more than once. Often the texts were subjected to extensive revision from printing to printing - an extreme case is that of "Romagna," whose evolution from an original "Colascionata $1^{a}$ a S. Ferrari Ridiverde" Nava studied in a previous article, only to conclude that the differences between the two versions were so great as to warrant our considering them two separate poems. ${ }^{9}$ Even after the publication of the third edition of the Myricae volume, Pascoli continued to publish independently (and to revise, once published) poems which would eventually find their way into the definitive corpus.

Myricae, then, was a book that grew. A second, enlarged edition came out, hard on the heels of the first, in January 1892, largely, it seems, on the insistence of Pascoli's original publisher, Raffaello Giusti, a bluff tradesman who, one suspects, in his subsequent strained relations with the poet, may have been as much sinned against as sinning. In this edition, the number of compositions increased to seventy-one. The third edition, dedicated to the memory of the poet's father, with illustrations in the decorative taste of the day, had 116 poems, forty-four more than the second, and was published in 1894 . For the first time, after a new version of the preface, destined to remain substantially unaltered in all ensuing editions, the long lugubrious keening poetic rhapsody, "Il giorno dei morti," opened and set the tone of the collection. ${ }^{10}$ It was only with the fourth edition (1897) that the volume reached what was to all intents and purposes its present form. Only four new poems were added in the fifth (1900) - bringing the total to the definitive number of 156 - and, apart from a thoroughgoing revision of the text for the seventh edition (1905), subsequent changes through the ninth (1911), the last edition published in the poet's lifetime, concern relatively minor details of spelling and punctuation. 11

Myricae's growth, however, was qualitative and not simply numerical. No less than the microtexts, the macrotext radically altered its structure from one edition to another. The order of the 
compositions was restlessly rearranged, as was their division into sections. The number and titles of the sections grew steadily, more than keeping pace with the corresponding expansion of the number of compositions. It is as if the poet, without a faith but unable to accept our existence as meaningless, for whom poetry meant the interrogation of "particular things," and for whom to write was to attempt to discover, by transcribing the signs of the phenomenal world, clues to the world of the absolute; as if we were convinced, on the level of the articulation of the whole as well as on that of the individual utterance, that the proper arrangement of the clues, the correct disposition of the random fragments, might yet yield a key to the Sense hidden by the senses, crack as it were the combination of appearances, and place him and us, to quote a poet whose debt to Pascoli is by no means merely lexical, "nel mezzo di una verità."12

The publishing history of Myricae can be followed in much closer detail than space allows us here in Nava's chapter on the printed sources ("Descrizione e ordinamento delle stampe," pp. CCLIIICCCIV). The tables assembled there permit the reader to follow the vicissitudes of the volume, and of its constituent elements, from first to last, and to trace in detail how its present structure evolved. They illustrate the precise contents of each edition and how these contents were reordered as the volume grew. They also show which of the poems were first published separately, and where and when, and at what point these disjecta membra became part of a corpus. ${ }^{13}$ This is, however, by no means the whole story. Nava himself is quick to point out (p. XI) that his initial hypothesis of a close relationship between the date of first publication of a given poem and its date of composition was often disproved by subsequent research. The importance of considering the dates of composition of Pascoli's works rather than their dates of publication is one of the chief acquisitions of recent Pascoli criticism. Credit for convincing us of this necessity must go first and foremost to Furio Felcini, who twenty years ago was already insisting on the complex and tormented prehistory of the poet's nugae, on the rashness of a number of critical judgments based on the misleading evidence of the dates of publication, and on the pressing need for an exhaustive survey of the manuscript sources as a preliminary to any new critical reading of the poet's works:

Il mancato accertamento della cronologia dei singoli componimenti pascoliani e l'impossibilità di accedere alle varianti dei medesimi hanno contribuito, nell'ambito propriamente critico, al determinarsi e al persistere di conclusioni e direzioni spesso errate. Pertanto, l'ordinamento 
cronologico delle poesie pascoliane e delle varie redazioni di esse (dagli abbozzi e dai primitivi disegni agli stessi rifiuti e cancellature) deve considerarsi come fatica preliminare a una rilettura critica del poeta. ${ }^{14}$

Most later critics have heeded Felcini's warning and have as a consequence been less sweeping, more guarded and circumspect in their critical pronouncements. No one before Nava, however, had taken his advice so completely to heart. For surely the signal merit of these volumes is that they make available for the first time to students of Pascoli's arduous program of self-construction that portion at least of his working papers that bears on the painstaking elaboration of Myricae ("opera," in Nava's words, "quant'altre mai sperimentale per i suoi tempi," p. XI). The definitive critical text of the finished work which opens the second volume is a milestone in Pascoli scholarship, an accomplishment that will remain standard. The contents of box $L$, however, are nothing less than a revelation, a new point of departure. There are still many other boxes in the Pascoli archive, whose contents remain a mystery. Let us hope that the quality of Nava's impeccable achievement, the fruit of almost a decade of study, will encourage rather than discouraging emulators. 15

Nava's vade-mecum to the papers is articulated in two parts. The first, included in the introductory volume under the rubric "Descrizione e ordinamento dei manoscritti" (pp. C - CCXXVII), consists of a complete description of the appearance and contents of each of the 217 items kept in the thirty-seven envelopes of box $L$, plus 47 related pieces found in other boxes, along with nine additional documents from locations outside of Castelvecchio. Each item is assigned a number by Nava (from CPI to CP264 for the material preserved at Casa Pascoli), which will be referred to later in his transcription of the entries relevant to Myricae, thus facilitating cross-reference and allowing the reader to situate the fragments transcribed in their over-all context. Rarely were the original manuscripts dated. For the most part they consist, not of bound notebooks with sequential entries on consecutive pages, but of densely written loose leaves of varying dimensions, the largest measuring $210 \times 310 \mathrm{~mm}$., the smallest little more than scraps, half the size of a $3 \times 5$ card.10 The minute writing - not always the fine and meticulous hand on which Pascoli so prided himself - besides changing over the years, tends also to reflect his passing moods, now betraying the impatient excitement of inspiration, now a movement of discouragement, now one of confused agitation. The contents of a given page are often extremely 
heterogeneous, sprawl higgledy-piggledy at all angles on the page, and are by no means easy to decipher.

The first conclusions of a general nature to be drawn from the papers have to do with the mechanics of Pascoli's working method. They indicated that, to the disparity between date of publication and date of composition, there must be added a second diachronic interval - that between date of composition and date of first ideation. Or, to put it more accurately, they show that the notion of a single date of composition, however approximate, is quite simply not appropriate, that the initial inspiration precedes the finished product in most cases by many years, and that, between the terminus a quo and the terminus ad quem, the poet habitually returned to modify his text on any number of unspecifiable later occasions. A corollary, suspected by one or two previous critics, urged by Felcini, and now fully confirmed by the evidence, is that the impression of a series of successively conceived entities, conveyed by the staggered chronological distribution of the various collections - Myricae, Poemetti, Canti di Castelvecchio, Poemi conviviali, Carmina, etc. - is to a large extent illusory. The Canti di Castevecchio, as their common Latin motto suggests, are a continuation of Myricae. The distinction in Pascoli's mind between these and the remaining volumes seems originally to have been a fairly external one of "genre," based on language and subject matter. Each poem was conceived punctually. Its possible inclusion in a class was an afterthought. The interesting thing is that the afterthought tended to generate other poems of the same kind. And, while it is true that the poems in the later volumes, in contrast to the fragmentary and impressionistic Myricae, display a more ambitious architectural and narrative structure, the will to narrate (the narratability of the world implying some kind of guarantee of its meaningfulness) was present practically from the start - although initially it found an outlet, not in the Italian poems, but in the Latin carmina (which dealt, in any case, with an imaginatively recreated world to which the poet himself gave meaning). ${ }^{17}$

Now that Nava has given us access to the worksheets, the extent to which the growth of the different collections was synchronous and symbiotic can begin to be fully appreciated. ${ }^{18}$ One or two examples may not be out of place. Although the bulk of the Myricae manuscripts belong to the period after Pascoli had settled with his two sisters in Livorno, to the years 1889-93, one of the oldest of the surviving documents dates from almost a decade earlier, around 1882, the year he finally took his degree at Bologna and was posted to his first teaching job in Matera. It contains, in addition to details of a projected collection of poems which was 
to have had the strikingly modern (Sbarbaresque to be precise) title of Detriti, the first draft of a poem entitled "Tiberio poppante." The poem "Tiberio," now one of the Poemi conviviali, was not published until 1896, some fourteen years later, in the Florentine periodical Marzocco; while, as a collection, the Conviviali had their first edition only in 1904. Or again, according to Felcini's tables, the publication in periodicals of individual exemplars of the narrative Poemetti did not begin until 1896, while the first collected edition (Firenze, Paggi) appeared in 1897. The famous "Digitale purpurea," however, was unknown to the public until it came out separately in March 1898, and it did not become part of the collection till the second edition (Milano-Palermo, Sandron, 1900).19 But, in documents which can be assigned with certainty to the year 1892, in the heart of the Myricae period, the title "La digitale," accompanied by the metrical specification "terzine," crops up not once but several times.

The contradictory nature of Pascoli's personality thus receives further illustration from these working papers, which can be said to be the scene of a struggle between the poet's method of "accentuato frammentismo compositivo" (p. CCCVIII) and a no less powerful "volontà quasi ossessiva di costruzione pianificata della propria opera" (p. XII). The latter is most vividly attested precisely by those long columns of titles which occur, alongside the other jottings, on practically every page. Difficulties of dating and ordering make it impossible to determine in each and every instance the exact status of the composition to which the title refers. It is clear, however, if from nothing else from the fact that the papers examined by Nava yielded, in addition to copious listings of the titles of extant poems, a further five hundred titles of poems (or books of poems), in both Latin and Italian, planned but never apparently completed (pp. CCXLI-CCLI), that the titles often refer to works existing nowhere else but in Pascoli's extraordinarily fecund and retentive imagination. 20

The second part of Nava's guide to the Myricae papers, the actual transcription of the poet's autographs, is found in the second volume, immediately after his critical edition of the definitive text of the poems, based naturally on that of the ninth (1911) edition, the last one published during Pascoli's lifetime. In this section, the editor provides, for each lyric, in the order in which it appears in the final text, an interpretative transcription of all of the notes and drafts relative to its composition. Insofar as a detailed reconstruction is possible - on the basis of external criteria (paper, ink, style of handwriting) and, more usefully, internal criteria (linguistic, stylistic, and metrical considerations) - this material is presented 
in the order of its having been written. It is considerably easier, incidentally, to place the poet's notes in order than it is to assign precise dates to them. Some idea of the richness of the lode - and it is a strike bound to delight and invite the "critico degli scartafacci" - can be obtained if we consider that the text of the definitive edition, printed, with ample margins, one (usually short) poem to a page, occupies only the first 243 pages, whereas the text of the transcriptions, printed sequentially with no large blank spaces, occupies the remaining 326 (pp. 245-571). As we noted earlier, the descriptive catalogue in the first volume and the present transcription are complementary. Together they provide a clear picture of how these texts are related in their context to each other and to the rest of the contents of a given page. The amount of preparatory material varies considerably from poem to poem, but there are very few of the 156 for which no manuscript draft exists. ${ }^{21}$

There are interesting parallels (and perhaps even more interesting differences) between Pascoli's habits of composition and those of his contemporary D'Annunzio. Both poets start frequently from prose jottings of their acute sensory impressions of natural phenomena. Anyone, however, who has had occasion to compare the taccuini of D'Annunzio with the poems which derive from them, cannot fail to have been struck by the extraordinary coincidence, not only in content but in phrasing, between the initial observation (already heightened in tone, more incantatory and evocative than realistically descriptive) and its eventual utilization in the context of a finished lyric poem. A comparatively unrevisited document of this spontaneous mode of composition is the extended fragmentary prose poem Notturno, scrawled blindly on continuous ribbons of paper as he lay in bed convalescing from a partially detached retina incurred in a flying accident in 1916. For Pascoli, on the other hand, whose vocabulary and syntax are usually simpler and less exotic (in the "genere miricesco" at any rate), and who might at first blush appear to have been the more facile of the two, the elaboration of that original perception is anything but immediate and instinctive. Rather, it is the outcome of a complex process of trial and error, a long and meticulous exploration, in the presence of a constantly vigilant critical faculty, of its psychological "aura," its suggestions, implications, and "soprasensi," aimed at producing a verbal artifact charged with all the psychic emotion he had sensed latent in the scene. 22

Be that as it may, whether the poet's tongue produced "quasi come per se stessa mossa" immediately serviceable iuncturae, or whether the verbal elaboration of his insights took time and effort, both Pascoli and D'Annunzio are clearly modern, in the broadest 
sense of the word, in foresaking the traditional oratorical and ratiocinative model of composition, a model which still appears, for instance, to have shackled somewhat the efforts of the young Leopardi. (Had he considered it, Pascoli might well have repeated, apropos of this aspect of the poet's technique, his well known remarks about another charachteristic of his admired predecessor which he felt separated him from the great Romantic: "E io sentiva che, in poesia cosí nuova, il poeta cosí nuovo cadeva in un errore tanto comune alla poesia italiana anteriore a lui: l'errore dell' indeterminatezza. . .") Leopardi's prose outlines must be among the last examples of the tenacious survival of the classical distinction between form and content, of a prose content, that is, which it is the poet's task to versify and to clothe in modes appropriate to poetry and in an appropriate diction. I am thinking, not so much of the drafts of the patriotic canzoni, which, even in their finished versions, suffered from the imposition of a too conspicuous rhetorical structure, as of the outline of a poem so untraditional as "L'infinito," with its rationalistic insistence that all grammatical relationships be made quite explicit through a sustained periodic syntax.23

Given the intricacies and obliquities of Pascoli's method, the poet's working papers contain many surprises, of which we can mention but a few, in the hopes of whetting the reader's appetite for more. ${ }^{24}$ The ballad stanza, "Il lampo" ("E cielo e terra si mostrò qual era"), a much anthologized piece and too well known to need quoting in full here, appears first in the third edition (1894) and does not acquire its virtuoso companion piece "Il tuono" until the fifth (1900). A suspicion, based upon a reading of the texts, that the former is more poetically motivated, indeed central to the canon, while the latter, an undeniable tour de force, is to be classed along with the parasitic afterthoughts we spoke of earlier, finds striking extratextual confirmation in the minute of a preface to the third edition, never published, written sometime around August 10 1892, on the twenty-fifth anniversary of his father's violent death. The passage is one of many in which Pascoli obsessively reconstructs the circumstances of the murder, attempting to put himself in his father's place:

I pensieri che tu, o mio padre benedetto, facesti in quel momento, in quel batter d'ala - Il momento fu rapido ... ma i pensieri non furono brevi o pochi. Quale intensità di passione! Come un lampo in una notte buia buia: dura un attimo e ti rivela tutto un cielo pezzato, lastricato, squarciato, affannato, tragico; una terra irta piena d'alberi neri che si inchinano e si svincolano, e case e croci - Oh! qualche volta io ripenso quel tuo pensiero e mi fremono nella gola le parole che tu non potesti dire $-E$ non le posso dir io: ma mi stringono la gola e il cuore mortalmente. ${ }^{25}$ 
"Il lampo," then, is no description of a natural phenomenon, but an impossible attempt to penetrate an inscrutable psychic moment, to see the universe through the eyes and mind of a dying man. Moreover, it states an inconsolable metaphysical conclusion. "Cielo e terra," as the singular verb betokens, are here a unit and mean "the sum of things," heaven and earth. On the point of death, they reveal their secret - a radical and dreadful emptiness.

The "ottava siciliana" entitled "Notte" is slightly less well known. This mannered interior with its overtones of medieval romance was among the twenty-two poems which made up the first edition (1891), and is indeed one of the earliest documented of the Myricae, going back, it seems, to 1883-4, when the poet was working on "Colascionata $1^{a}$," dedicated to "S. Ferrari Ridiverde" and later to develop into "Romagna." It is in fact a spin-off of that poem, an initial version being found in the margin of CP17. In its final form, "Notte" (which for a while had the title "Rovaio") closes the section "Dolcezze," two thirds of the way through the definitive volume. It is evident, however, from the chivalric allusions, that it has a more casual connection with the early sonnets ("Rio Salto," "Il maniero," "Il bosco," "Il fonte," which appear together in the second section "Ricordi"), as well as with such poems in the posthumous Poesie varie as "Echi di cavalleria" and "Astolfo." It is, however, less stilted than they are, less obviously "literary" in inspiration:

Siedon fanciulle ad arcolai ronzanti, e la lucerna i biondi capi indora:

i biondi capi, i neri occhi stellanti volgono alla finestra ad ora ad ora:

attendon esse a cavalieri erranti che varcano la tenebra sonora?

Parlan d'amor, di cortesie, d'incanti: cosí parlando aspettano l'aurora.

The stylized wool winders talk, as they sit at their cottage industry, of deeds of love and courtesy and of enchantments. They may be listening for the hoofbeats of knights errant, but whether they are likely to hear them in actual fact or in their imaginations is not made clear. There are no clues to chronology, the adventures referred to have in any case passed into common lore and could be recounted at any fireside, the scene exists outside of time. Certainly, it would not appear to have anything to do with the fall of Troy in 
1184 B.C. And yet, we learn from the drafts and a note cited by Nava that the "fanciulle" were originally "greche," and that the source of the poem's evocative final line is in the last lines of Book VIII of the lliad. 26

One of the most famous lyrics in Myricae is "L'assiuolo." It was first published in the Florentine Marzocco on January 3, 1897. The memorandum book CP245 contains a first draft in prose, datable, according to Nava, toward the end of 1894 or at the beginning of 1895. In these notes, there is no mention whatsoever of the bird of ill omen and harbinger of death:

La luna c'era? io non la vedevo ma i grandi alberi neri parevano alzarsi e guardare verso lei. Un cielo chiaro, con poche stelle. Da un canto un nero di nuvole che lampeggiava. Poche le cavallette e qualche cicala, appena. Tratto tratto uno stormir di foglie.

Gli alberi parevano, grossi e toffus protendersi e stare in contemplazione. Campanellini d'oro minuti scossi sistri delle cavallette passavano a quando a quando: rispetto loro le cicale parevano rane. 27

The two aspects of the scene that are particularly insisted upon are the apparent animation of the trees, which seem to strain upwards towards the invisible moon - a motif twice repeated and the contrast between the treble chirping of the grasshoppers and the basso continuo of the cicadas. What especially fascinates the poet's hypersensitive ear, in this instance, so to speak, of musical relativity, is the dialectic of sounds whereby the emergence of the bright high-pitched tinkling of the grasshopper so darkens and deepens the bourdon carried by the cicadas as to give the illusion of a shift in pitch and timbre on the part of the latter towards the absolute low in this symphony of nightsounds, usually represented by the absent frogs. It even looks as if he had planned to build his poem around this conceit, since it is placed in the climactic last stanza of the only surviving verse draft.

CP94 contains the first two stanzas of the poem in an already advanced phase of composition. Below them are a series of notes and variants for the final stanza: "di sistri minuti/di piccoli crotali d'oro / scotevano i sistri d'argento / minuti cosí, che / pareva un gracchiare / una rana / la tarda cicala: "In addition to crowding over into the right-hand half of the page, the writing becomes smaller and smaller as we move down, until these last, interrupted, jottings are so tiny as to be scarcely decipherable, betraying perhaps the diffidence and lack of conviction with which they were written. Across the bottom of the page, starting well over to the left, and written in a large bold hand, probably when the poet returned to the page later, is the arresting comment: "Sí: ma allora non è più la 
poesia, ma la spiegazione della poesia. $\mathrm{Ci}$ vuole abnegazione. Esempio: tintinni a invisibili porte." Brief and passing though it is, I do not think I am reading too much into this crytic self-admonition in calling it the best evidence the worksheets offer of how totally self-aware was the practical implementation of that symbolist poetic of reticence professed elsewhere in Pascoli's writings:

Il poeta ... non s'impanca a dir tutto, a dichiarar tutto, a spiegar tutto, come un cicerone che parlasse in versi; ma lascia che il lettore pensi e trovi da sé, dopo avergli messo innanzi quanto basta a capire. ${ }^{20}$

Contini is right to link the name of the so-called "provincial" Pascoli with those of Verlaine and Mallarmé. Let me close by reminding the reader of one typical statement by Mallarmé, in which he takes his distance from the poets of the Parnassian school. It is a statement which Pascoli would have had no difficulty at all in subscribing:

Je crois ... que, quant au fond, les jeunes sont plus près de l'idéal poétique que les Parnassiens qui traitent encore leurs sujets à la façon des vieux philosophes et des vieux rhéteurs, en présentant les objets directement. Je pense qu'il faut, au contraire, qu'il n'y aît qu'allusion. La contemplation des objets, l'image s'envolant des rêveries suscitées par eux sont le chant: les Parnassiens, eux, prennent la chose entièrement et la montrent: par là il manquent de mystère; ils retirent aux esprits cette joie délicieuse de croire qu'ils créent. Nommer un objet, c'est supprimer les trois quarts de la jouissance du poème qui est faite de devenir peu à peu: le suggérer, voilà le rêve. C'est le parfait usage de ce mystère qui constitue le symbole: évoquer petit à petit un objet pour montrer un état d'âme, ou, inversement, choisir un objet et en dégager un état d'âme, par une série de déchiffrements. ${ }^{30}$

This is how Pascoli would have talked, had he been born in the second arrondissement and not San Mauro. What was that you said about Cleopatra's nose?

\section{Vassar College}

\section{NOTES}

1 What Ant and Bee found in box $\mathrm{L}$ was a lost ladder, a lost lamb, and a lost lollipop. See Angela Banner, Ant and Bee and the ABC (New York, 1966), p. 57. Among the critics who have commented upon the poet's deliberate frustrating of our expectations is Cesare Federico Goffis, who speaks, for example, of "le continue incertezze e la voluta confusione pascoliana," in Pascoli antico e nuovo (Brescia, 1969), p. 314. But any reader of Myricae will recall the arresting and disorienting opening of the emblematic "L'assiuolo" ("Dove era la luna?..."), while the "Nebbia" invoked in a poem of that title from Canti di Castelvecrhio (we 
are perhaps reminded of "the yellow fog that rubs its back upon the window panels," so insistent a presence in the poetry of the young T.S. Eliot) curls no less sinuously through the Latin verses ("aut puer, I aut virgo . . I circum per nebulam forsitan audiat / quae dixi gracili carmina tibia.") The examples could be multiplied. Pascoli's is a world of drifting obfuscating mists, of estranged perspectives, of wandering landmarks, of bewilderingly shifting viewpoints, a world in which we are invited to see our surroundings magnified through the distorting eye of a ruminant ("Il bove," "Il torello") or to cling to a blade of grass "per non cadere in cielo" ("Il vertigine"), a world in short in which we are continually thwarted of the reassurance of familiar bearings, while our sense of the solidity that underlies appearances is systematically subverted.

2 Giovanni Pascoli, Muricae. Edizione critica per cura di Giuseppe Nava. Autori classici e documenti di lingua pubblicati dall'Accademia della Crusca (Firenze, 1974), 2 vols., CCCVIII + 595 pp. Nava's first volume contains an historical and critical essay, "Storia di Myricae," illustrating the growth of Myricae and the poet's gradual discovery of his individual poetic voice. There follows a meticulous description of the manuscript and published sources. In addition to the critical texts of the poems, the second volume provides a precious transcript of the working papers, making available for the first time an extraordinary wealth of unpublished material. Nava's interpretative essay shows him to be as acute an exegete as he is an impeccable editor. This rare combination of "filologia" and "critica" makes him a worthy disciple of his teacher, Lanfranco Caretti. Since the publication of the volumes in question, Nava, well known to students of Pascoli even before their appearance as the editor of the best brief anthology on the market - Giovanni Pascoli, Poesie. Scelta con introduzione, note, appendice di prose e antologia critica a cura di Giuseppe Nava (Bergamo, 1971) - has published, in Enrico Malato's fine series, "Testi e documenti di letteratura e di lingua," an edition for non-specialists of the complete Myricae, with extensive critical commentaries on all the poems - Giovanni Pascoli, Myricae, a cura di Giuseppe Nava (Roma, 1978).

3 Carrying out her brother's intentions according to her lights, Maria brought out posthumously the Poesie varie, the volume of translations entitled Trailuzioni e riduzioni, and, with the assistance of the Piarist priest, Fr. Ermenegildo Pistelli (the author of several literary works published pseudonymously under the name Omero Redi), the collected edition of the Latin poetry. She also added without authority - in subsequent editions of the already extant volumes in the canon, one or two of the poems she came upon among her brother's papers (see $\mathrm{n} .11$ below). The poet's correspondence in particular, contained in the lower-numbered boxes, furnished her with valuable documentation when she came to compose - and later, at the age of almost eighty, after the original MS. had been destroyed in a Turin air raid, to reconstruct practically from memory - her monumental biography of Giovanni - see Maria Pascoli, Lungo la vita di Gioranni Pascoli. Memorie curate e integrate da Augusto Vicinelli (Milano, 1961). Further glimpses of the unpublished papers were afforded by Pio Schinetti, "Pagine inedite di Giovanni Pascoli," Il Secolo XX, (May 1912), 377-92; by G.B Pighi, "Inediti pascoliani dalle carte di Adolfo Gandiglio," Convivium, XXII (1954), 712-24; by Carlo Pellegrini, "Esercizi poetici in lingua francese di Giovanni Pascoli," in Studi in onore di Italo Siciliano, Biblioteca dell'Archivum Romanicum, Vol 86, Pts. 1-2 (Firenze, 1966), II, 963-73; and, most recently, by Alfonso Traina, "Poesia in fieri. Dalle carte del Pascoli latino," Belfagor, XXIII (1968), 517-31, and "Preistoria di Thallusa," Belfagor, XXV (1970), 71-80. A good proportion of these materials have to do with the Latin poetry. It seems that some of the documents published by Schinetti have since disappeared, in spite of Maria Pascoli's assertion (op. cit., p. 38n) that all of the writings were now in her possession. Antonio De Lorenzi, for example, was not able to trace the MS. of the play, whose title, being proverbial, has a Mussetian ring, D'asse si trae chiodo con chiodo, mentioned in Schinetti's article. See Giovanni Pascoli, Testi teatrali inediti, a cura di Antonio De Lorenzi (Ravenna, 1979), p. 10. 
4 When it came to his relationship with Maria, even Pascoli himself had to admit the inadequacy of the traditional lexicon of kinship: "Io non so se più madre gli sia / la mesta sorella o più figlia." Their intimate acarpous sodality lasted a lifetime. After the death of Giacomo ("il piccolo padre") in May 1876, the poet became the oldest of the five surviving members of what had been, a few short years ago, a flourishing family of twelve. He demanded total emotional commitment from his siblings; with the result that in his eyes the family split symmetrically into the "good" brother and sister - Raffaele and Maria - and the "bad" ones - Giuseppe and (after 1895, when, aged thirty-two instead of leaving the house she shared with Giovanni and Maria in Livorno for their new house in Castelvecchio, she chose to marry someone else) the once beloved Ida. Biagini, Pascoli's first biographer, claims to have had it from Ida that Giovanni, on his deathbed, murmured in her ear: "Ida, io muio vergine" - see Mario Biagini, Il poeta solitario. Vita di Gioranni Pascoli (Milano, 1956), p. 485. The possibility of any such confidence ever having passed between them was piously denied, on flimsy circumstantial evidence, by the devoted Vicinelli, in his supplement to Maria's life of her brother (p. 1020n.), but not until four years after Ida had died at the ripe old age of ninety-three. The interesting thing is not so much the truth or the falsehood of the report as the fact that Ida felt that some such clarification was called for. Giovanni's and Maria's lives together were filled in fact with bitter barren longing for their unborn children, a sense of unfulfillment expressed by Maria in the poems written by her and included by Giovanni in the notes to the Canti di Castelvecchio, while an anguished aching meditation upon his own sterility produced - from "Il vischio" to "L'etera" some of the starkest and most intensely felt compositions in all of her brother's work. Fr. Pistelli once regretted to Luigi Russo the odd circumstance that the poet of the "fanciullino," in all other respects a perfect Christian gentleman, showed in practice little love for or patience with children. The fault is far from uncommon among aging bachelors, and for Pascoli the schoolteacher there were a series of exceptions to the rule. They were not handsome children, but plump timid boys who must have reminded him of himself as a child. One of them was the Antonio Masi (nicknamed with professorial humor "Antonomasias") for whom he wrote the touching Latin sapphics (XXIV) which begin: "Nullus in sola mihi ludit aula / ora qui vultu referens paterna / natus in multos animum fugacem / proroget annos." That Pascoli had guilty unavowed incestuous fantasies of parenthood which directly involved Maria can be deduced from the truly singular short story, "Il ceppo," which first appeared in La Vita Italiana in 1897 (the year of the fourth edition of Myricae) and has recently been republished. See Giuseppe Zaccaria, "Scheda per il Pascoli narratore," Il lettore di provincia, 29-30 (1978), 5-15. I hope I will not be accused of being disingenuous if, in the face of Arbasino's hilarious and hair-raising revelations - see Albert Arbasino, "Cip-cip...," in Certi romanzi. Nuova edizione seguita da La Belle Epoque per le scuole (Torino, 1977) - I put in a word for the perfect innocence and candor of their relationship. In such an intimate and jealous labyrinth of reciprocity, the parental and filial roles are completely interchangable. In one of his Latin epigrams (XXVI), it is Giovanni himself who becomes the tender father, Maria the little girl in need of someone to help her if she stumbles: "Ergo iter inceptum perges, soror: at quid opportet / auxilium precibus sollicitare meum? / Linquere, quod nimium est, gnatem me credis euntem / lapsantque piam posse negare manum?" (The "iter inceptum" by Maria, according to Gandiglio's Appendix criticn, was the study of Latin composition. The distichs entitled "Precatio" (XVIII), which evoke the unquiet ghosts of their lost parents, were originally composed by Giovanni, written out in a jumbled order, and given to her as a puzzle in metrical reconstruction. If the study of Pascoli's literary output teaches us one thing, it is that there are no minor occasions!) Mother, sister, daughter; father, brother, son. The conjugal role is the only one omitted from the catalogue. Unlike the nurturing and dependent roles, the roles of husband and wife are not reversible. Also, of all family ties, it is the only one which is 
absolute and exclusive, impenetrable to the child. The mystery that Maria and Giovanni could not know. Without the biological promise of reincarnation, the sublime (and ridiculous) task the two set themselves - with heroic and terrible sentimental versatility - was to take the place, each for the other, of an entire family. Surely there can be no greater, that is more hopeless, love.

5 Alfonso Traina, $1 l$ latino del Pascoli. Saggio sul bilinguismo poetico 2nd. ed. (Firenze, 1971). The hint of special pleading was aptly brought out by Pier Vincenzo Mengaldo in a review, "Un libro sul latino del Pascoli," now reprinted in La tradizione del Novecento. Da D'Annunzio a Montale (Milano, 1975). Traina's is one of the most useful recent contributions to the interpretation of Pascoli's poetry; and not simply of the Latin carmina. So is the work by Goffis cited in n. 1, also ostensibly concerned primarily with the Latin Pascoli ... Giogio Barberi Squarotti's Simboli e strutture della poesia del Pascoli (Messina-Firenze, 1966), and the chapter on Pascoli by the poet Mario Luzi in Emilio Cecchi and Natalino Sapegno (eds.), Storia della Letteratura Italiana. Vol. VIII: Dall'Ottocento al Novecento (Milano, 1969), pp. 613-683, are other recent attempts at a global treatment. Gian Luigi Beccaria's latest collection of essays - L'autonomia del significante: Figure del ritmo e della sintassi: Dante, Pascoli, D'Annunzio (Torino, 1975) - contains a wealth of documentary material and a very perceptive analysis of some of the stylistic effects achieved in the Italian verse.

6 The title "Myricae" had made its first appearance the year before, at the head of a group of nine short poems published in the August 10, 1890 issue of the Florentine periodical Vita nuova. The date, the feast day of St. Lawrence, is significant, since it marks the twenty-third anniversary of the death of Ruggiero Pascoli, the poet's father, ambushed and shot in the head as he drove home from the market in Cesena on August 10, 1867. Eight of the nine poems form in fact the nucleus of the 1891 presentation volume. The dedicatee was Ratfaello Marcovigi, who had been a fellow student of Pascoli's at the University of Bologna. The friendship with Marcovigi was one of those which lasted. "Biondino," as he continued to be called, was the only person outside the immediate family on hand to assist the poet as he died, agonizingly slowly, in Bologna during March and April of 1912. The ninth composition in the Vita nuova group ("Sin che parlasti, il vento") was not included in the volume. It was published by Maria among the Poesie varie, as the third of four brief lyrics in the series "Primo ciclo."

7 It would be wrong on the other hand to exaggerate the fortuitousness of the 1891 edition. The majority of the working MSS. transcribed by Nava can be dated between 1889 and 1893 . The year 1891 , then, is central to this period of intense creative activity.

8 Although not previously published, "Mare" was by no means a recent composition. It is in fact one of the earliest surviving poems to be included in Myricae, the first drafts dating back as far as 1882 . In verse form it is a "rispetto" and a rather good example of the interest in folk poetry that Pascoli shared at the time with Severino Ferrari. Adriano Seroni cites any number of instances from nineteenth-century collections of Tuscan folksongs, showing that the poem's first verse, "M'affaccio alla finestra, e vedo il mare," is one variant among many of a common opening formula for such compositions. See his article, "Ancora sul Pascoli delle Myricae," in Nuove ragioni critiche (Firenze, 1954), pp. 123-36. A previous piece by Seroni, "Per una storia delle Myricae," can be consulted in Apologia di Laura ed altri saggi (Milano, 1948), pp. 79-120. Though it is not the lyric of the title, interesting observations on the poem "Mare" can be found in Giorgio Orelli, "Per una lirica del Pascoli," Strumenticritici, 21-22 (October, 1973), 283-90. It is worth mentioning here that the eight madrigals so far composed for the "narrative" cycle "L'ultima passeggiata" - regarded by some critics as among the poet's most characteristic work - were not included in the gift edition for Marcovigi's wedding, for the simple reason that they had already been presented to another friend, Severino Ferrari, at his wedding in September 1886 . 
9 The published texts of many of these poems, as they first appeared, before being revised for inclusion in the Myricae volume, a re reproduced in an appendix to Antonio Di Pietro, Il primo Pascoli. Dai versi gionanili alla seconda edizione di Myricae (1869-1892), (Bari, 1963). Pascoli's reluctance to publish a collected volume of his poetry should remind us that, in spite of any reputation he may have to the contrary, he was an exacting self-critic. Much of his iuvenilin was later rejected and never appeared in any of the collected volumes. To date there is no satisfactory comprehensive edition of these early works. The Poesie varie, published after his death by Maria - and now most readily consulted in the second volume of the ninth Mondadori edition of Giovanni Pascoli, Poesie (Milano, 1958) - are incomplete and inaccurately dated. Other poems are included in the "Appendice di poesie giovanili disperse" in Giorgio Petrocchi, La formazione letteraria di Gionanni Pascoli (Firenze, 1953); a few, omitted from the Varie, are in Maria's life of her brother, cited in a previous note; and one or two first saw the light in Vicinelli's Giovanni Pascoli, Antologin lirica (Milano, 1962). The new edition of Pascoli's "stravaganti" promised by Nava in a footnote to his article on the successive versions of the poem "Romagna" - "La storia di 'Romagna' e la poesia giovanile del Pascoli," Studi di filologin italiana, XXVII (1969), 188n. will no doubt live up to the superb standard set by the present volume, and become a similarly invaluable contribution to our knowledge of these crucial formative years. Studies of Pascoli's difficult road to self-discovery as a poet, in addition to those already cited, include C. Curto, "La poesia di Pascoli avanti le Myricae," Convivium, IX (1937), 624-50; Pietro Bonfiglioli, "Severino, Pascoli e i 'goliardi'. Conformismo e opposizione nella scuola carducciana," Emilia, VII (1955), 238-44; Angelo Stella, "Sperimentalismo del primo Pascoli," Paragone, XII, No. 148, (1962), 3-27; Raffaele De Bello, "Dalla seconda alla terza edizione di Myricae," in Studi per il centenario della nascita "li Giovanni Pascoli publlicati nel cinquantenario della morte, 3 vols. (Bologna, 1962), III, 99-106; Antonio Domenicone, "La fase vitanovistica della poesia pascoliana," in Nuovi studi pascoliani (Bolzano and Cesena, 1963), pp. 63-76: Furio Felcini, "Introduzione" to Severino Ferrari, Tutte le poesie (Bologna, 1966), pp. 5-75; Ettore Caccia, Pascoli primo tempo (Venezia, 1968); and Giovanni Ponte, "La poetica di 'Foglie gialle' e la lirica giovanile del Pascoli," Rassegna della letteratura italiana, LXXV (1971), 71-92. Felcini has lately returned to this and related problems in his volume of essays, Indagini e proposte per una storia delle 'Muricae'. Alle origini del linguaggio pascoliano (Roma, 1976). Felcini is of course something of a pioneer in recent Pascoli studies. (See $n .14$ below). For this reason, it is all the more regrettable that, in a work parts of which cover much of the same ground authoritatively covered by Nava, Nava's edition is alluded to somewhat perfunctorily and not granted the recognition it is so richly deserves.

10 The preface to the second edition, however, already quoted one or two stanzas from this otherwise unspecified work in progress. The private therapeutic value of the poem can be inferred from the ritual manner of its composition, to the accompaniment, we are told, of uncontrollable tears and sobbing, on the anniversary dates of the family's many bereavements. See Maria Pascoli, Lungo la vitn, etc., p. 323.

11 For all practical purposes, the year 1897 marks the dividing line between Myricae and Canti di Castelverchio. It $w$ as in that year that the first of the poems later to be included in the Canti began to appear in periodicals and elsewhere. The first edition of the Canti came out in 1903. The shared epigraph implies that they were seen in many respects as a sequel to Myricae, a hypothesis borne out by the evidence of the MSS. On c. 24r. of CP 245, a memorandum book used between 1883 and 1897 , is a first mention of the title Canti di Castelverchio, while c. 30r. contains a "Programa per il MDCCCXCVI" which includes the entry " 2 a di Myricne". This cannot refer to a second edition, since by 1894 the third edition was already out. Farther along, on c. $51 \mathrm{v}$., we find the more explicit indication "Myricae. 2a serie o come / Poemetti polimetri," which must refer to the Canti. In the poet's correspondence, we find frequent references to "le nuove Myricae." The 
editorial vicissitudes of the Canti di Castelvecchio were not nearly so complex as those of the Myricae. The order of the compositions stayed substantially unaltered from first to last. The opening section, from which the book takes its title, grew from fifty-two to fifty-seven poems between the princeps and the fourth edition (1907), and thereafter remained stable. The number of poems in the section entitled "Il ritorno a San Mauro" was never changed. In the fifth edition (1910), the eight poems of "Diario autunnale" were added as an appendix. Two of the poems included in the Mondadori vulgate - "Il compagno dei taglialegna" and "La capinera," both of which Pascoli himself chose, for reasons of his own, not to incorporate - were actually introduced by Maria in the seventh edition (1914). For the printing history of the Canti, see Nadia Ebani, "Bibliografia e apparato delle stempe dei Canti di Castelverchio," Studio di filologia italiana, XXVIII (1970), 261-93. Her work is compatible with Nava's, as she follows an earlier article of his - "Bibliografia di Myricae," Studi di filologia italiana, XXV (1967), 211 22 - now absorbed into the present work. Her critical edition of the Canti di Castelvechio is eagerly awaited. In the meanwhile, she has published the notes and drafts relating to one of the most famous poems in the collection, "Il gelsomino notturno," along with her interesting critical conclusions. See Nadia Ebani, "ll gelsomino notturno nelle carte pascoliane," in Studi di filologia e di letteratura offerti a Carlo Dionisotti (Milano and Napoli, 1973), pp. 453-501.

12 In slightly misquoting yet another poet, closer in time to Pascoli, and speaking of Pascoli's "long immense et raisonné dérèglement de tous les signifiants," I do not think I am making excessive claims for his gnoseological subversiveness. Despite the promising beginnings charted in Teresa de Lauretis' intelligent article "Il Pascoli e lo strutturalismo: prospettive critiche," Forum italicum, IV (1970), 172-184, the structures of Pascoli's texts are still awaiting the full innovative potential of modern analytical methods.

13 This information was made available in part in the article by Nava cited in $\mathrm{n} .10$. For completeness and accuracy, it supercedes the account given by Augusto Vicinelli - "Storia bibliografica delle Myricae: I. Le varie edizioni," in Omaggio a Giovanni Pascoli nel centenario della nascita (Milano, 1955), pp. 9-25 - although Vicinelli does supply interesting additional anecdotic details. It might be well here, since the circumstance could lead to some slight confusion, to remind the reader that the useful tables (pp. CCLXX-CCLXXVI) of poems which have a history apart from the collection refer only - they claim to do no more - to poems eventually approved for inclusion in Myricae. The other poems published during this period, most of them printed by Maria among the Varie (but see n. 8 above), are not mentioned. Nava's second volume, to cite specific examples, has an appendix giving the rough drafts and definitive texts of three poems "Crepuscolo," "I sepolcri" and "Il principino" - first published in periodicals, later included in the second edition of Myricae, then dropped from the third. They are not listed in the tables.

14 Furio Felcini, "Premesse a una rilettura del Pascoli," Giornale storico della letteratura italiana, GXXXVII (1960), 61-82, rpt. in Studi per il centenario della nascita di G.P. pubblicati nel cinquantenario della morte (Bologna, 1962), III, 249.

15 A publication like Nava's makes us painfully aware of how much remains to be discovered concerning the true Pascoli. The long-standing querelle between "pascolisti" and "antipascolisti," as is customary with such squabbles, generated more heat than light, since it was waged for the most part over a mystified image or an illusion. For a fresh and honest assessment of the poet and his work, Pascoli criticism stands in urgent need of two things: to begin with, new editions of the rest of his works, based like this one on a careful scrutiny of all the available bibliographical evidence, including the autograph MSS., possible now that the archives have become accessible and the exclusive Mondadori rights have run out; and, in the second place, that the MSS. themselves be published, as far as possible in their entirety. For many of the works these tasks are under way. We have already had occasion to mention Giuseppe Nava's promised edition of the Varie, and Nadia Ebani's work on the Canti di Castelvecchio. 
In addition to these ventures, Elisabeth Piras-Rüegg published in 1974 her doctoral thesis, which consisted of the critical text and a commentary on "L'ultimo viaggio," the longest of the Poemi conviviali, and took into consideration the evidence of the evidence of the MSS. at Castelvecchio. See her Giovanni Pascoli: L'ultimo viaggio. Introduzione, testo, e commento, Kölner Romanistische Arbeiten, Neue Folge, Heft 43 (Genève, 1974). She has pronounced her intention of going on to edit the rest of the collection. No doubt, in doing so, she will take account of Laura Bellucci's "Per l'Anticlo del Pascoli," Studi e problemi di critica testuale, n. 8 (April, 1974), 172-183, and "Il Cieco di Chio e i Conviviali 'omerici'," Studi e problemi, etc., n. 11 (Oct., 1975), 174-187. Maria Serena Ricci Peterlin - in "Contributo al testo dei Poemetti pascoliani," Filologia e letteratura, XVII (1971), 282-312, and "Intorno a un testo dei Poemethi pascoliani," Studi e problemi di critica testuale, n. 7 (Oct., 1973), 212-241 - has given us a critical history of the texts of two of the Poemerti, respectively of the "La sementa" cycle and of "L'asino." As far as the Latin poetry goes, it was soon felt that the collected Carmina (2nd ed., Milano, 1954), a collaborative undertaking whose general editor was Pascoli's devoted former pupil Manara Valgimigli, represented, despite its very real merits, something of a missed opportunity. Steps are being taken to provide more reliable and better annotated texts. A number of volumes have already appeared, inspired for the most part, directly or indirectly, by the work of the eminent Latinist Alfonso Traina. These volumes generally present the text of a single Latin poem, accompanied by an introduction and commentary. The first such publication was Giulio Puccioni's Centurio, initially in the Annali della Scuola Normale Superiore di Pisa (1964), and later issued in a separate volume (Roma, 1968), closely followed by Pomponia Graecina, a cura di Alfonso Traina (Bologna, 1967), the two Saturae (Catullocalvos" and "Fanum Vacunae"), a cura di Alfonso Traina (Firenze, 1968), Fanum Apollinis, a cura di Emilio Pianezzola (Bologna, 1970), Phidyle, a cura di Paola Sommer (Firenze, 1972), Senex Corycius (Cilix), a cura di Cesidio De Meo (Bologna, 1974), and Reditus Augusti, a cura di Alfonso Traina (Firenze, 1978).

16 There are some exceptions. It is not unusual, for instance, for a few sheets to be folded in two and bound together with string to form an improvised homemade notebook. Furthermore, boxes LXXII, LXXIII, and LXXIV (each labelled Poesia ed altro. Quaderni vari) contain several commercially produced notebooks, many of whose entries bear directly upon the elaboration of Myricae. CP244 is a fairly bulky copybook consisting of 108 folios. Many of the pages are blank, and a number have been torn out. It appears to have been started in 1892 or 1893 and used for several years, at least until 1897 . CP245 is a smaller memorandum book of 63 folios, with entries from the same period, dating predominantly from 1894-5. Richest of all in Myricae materials is CP246, a copybook of 74 folios used especially in 1891-2 and recycled later, in 1896-7. None of these longer documents refers exclusively to Myricae. Each indeed is a "mélange adultère de tout," in which it is something of a feat to sort out and catalogue the entries. Although Nava does not (as far as I can see) broach the subject, it is difficult not to suspect Maria, in her excessive zeal, of tampering physically with the papers. The extremely irregular dimensions of the scraps, their torn or snipped edges, their preservation in separate envelopes, all suggests that she innocently compounded the already almost insuperable problems of dating and ordering the material by tearing out pages, possibly breaking up whole notebooks, and cutting up individual pages in order to distinguish materials belonging to different collections.

17 On Pascoli's narrative bent, see Claudio Varese, "L'elemento narrativo nel Pascoli," in Pascoli decadente (Firenze, 1964) and C.F. Goffis, Pascoli antico e nuovo (Brescia, 1969), especially Ch. ii ("Le strutture pascoliane"), pp. 17-32. It seems, incidentally, to be one of the factors behind the privilege accorded to folklore and ancient myth and legend in his work.

18 On the anecdotal level, this ought to have been the message of the legendary three tables, though in practice the set-up has tended to be used, misleadingly, 
to stress the separateness of Pascoli's various literary activities. That the staggered publication dates of the various volumes of the poet's arurre were likely to lead us astray, and that the notion of a descending parabola petering out in a total pedantic withdrawal into neo-Latin poetry was particularly false, was pointed out by Adolfo Gandiglio in essays written as long ago as 1912 and 1914 . See his Giovanni Pascoli poeta latino (Napoli, 1924), passim. Contini's comment that, given the variety and disparateness of the poet's ventures, the three tables were "piuttosto troppo pochi che troppi" - Gianfranco Contini, La letteratura italiana, Vol. IV: Otto-Novecento (Firenze, 1974), p. 130 - sounded a note of implied skepticism which is confirmed by the quite promiscuous confusion that prevails among the papers of the archive.

19 This is the edition reproduced by Edoardo Sanguineti in his impeccably annotated Giovanni Pascoli, Poemetti (Torino, 1971). In subsequent editions, the Poemetti were divided into Primi and Nuovi.

20 The typical effusion of Maria Pascoli's explanation of these lists of titles is remarkable for its anthromorphizing of the unwritten works - halfway between Myrrhine's unborn children in the conviviale, "L'etera" ("informi tra la vita e il nulla, / ombre ancor più dell'ombra esili, i figli / suoi, che non volle") and Pirandello's preface to his Seipersonaggi. The passage is found in her introduction to her brother's unpublished dramatic sketches. "Ci teneva, li amava, ne parlava con grande compiacenza e ne seminava i titoli qua e là in foglietti volanti e né suoi repertorii quasi temesse che si potessero credere dimenticati." Giovanni Pascoli, Nell anno mille. Sue notizie e schemi di altri drammi (Bologna, 1924), p. 39 (italics mine). For the recurrent theme of the "figli non nati," see C.F. Goffis, "La sopravvivenza fisiologica nei Poemata Christiana," Belfagor, XXII (1967), 681-95.

The original title of "Novembre" appears to have been "San Martino." At the stage represented by CP98 the title was "L'estate de' morti." This is, I think, a good example of the mnemonic function of many of these provisional titles, the final title being invented as an integral part of the system of the definitive text. Here, the working title epitomizes the poem in terms of the conceit which is to effect its closure, which, while it is by no means the poem's only justification, is nonetheless the point towards which it suspensefully moves. Were the finished poem to be entitled "L'estate de' morti," the surprise and satisfaction afforded by the epigrammatic ending would be lost. Even the earlier, less revealing, "San Martino" might lead the reader to supply the idea of a kind of summer before the poet wanted him to. The eventual title "Novembre" could scarcely be more restrained and non-commital. One of the first critics to recognize the importance of Pascoli's titles (rather than simply being irritated by them, like Croce) was again Claudio Varese in his Pascoli decadente (Firenze, 1964), p. 31.

21 There is no rough version at all among the papers of a score of poems: "Il rosicchiolo," "Pianto," "Il passato," "Nel cuore umano," "Il cacciatore," "Nozze," "Sorella," "Ida e Maria," "Nella macchia," "Vespro," "Stoppia," "In chiesa," "Il tuono," "Lontana," "Notte dolorosa," "Notte di vento," "Il bacio del morto," "Fiore d'acanto," "Viole d'inverno," and "I gigli." In the case of the apologue "Nozze," which appeared in print with the title "La rana e l'usignuolo," in two earlier versions, before being included in the second edition of Myricae, Nava prints the previous redactions as an appendix to the definitive text.

22 Nava's experience with the worksheets led him to two interesting general conclusions of a stylistic nature, which he was able to put to use in determining the order of composition of the fragments. In the first place, he discerned (and illustrated at length in the article on the two versions of "Romagna" cited in a previous note) a tendency on the part of the mature Pascoli to expunge lexical items with an archaic or literary flavor in favor of more current colloquial terminology. Secondly, it seems that, when it came to versifying an original intuition (often, as we have seen, set down in prose), the poet was wont to throw up, as it were, a rapid scaffold, consisting of the rime-words, with or without the initial words of the following line. The earlier stages among the drafts of a particular poem frequently display this characteristic phenomenon. 
We are reminded of an anecdote recounted by Manara Valgimigli in his introduction to the collected Carmina. "Io lo ricordo a Messina gli anni che gli fui più vicino: scriveva in certe sue cartelle lunghe e chiare, con quella sua calligrafia minuta che sempre saliva in su verso il finire della riga. Una volta, buttato l'occhio a una di queste cartelle dove c'era una serie di esametri, vidi che alcune righe avevano poche parole e l'esametro era incompiuto. - O questi? azzardai. - Sono le columnae, - mi rispose - i fulcimenta, le impalcature della costruzione; - e aggiunse, sorridendo: - Virgilio, a levarle tutte non fece in tempo ....-" Giovanni Pascoli, Carmina, a cura di Manara Valgimigli, 2nd ed. (Milano, 1954), pp. XXXII-XXXIII. D'Annunzio's notebook for Alcyone has been published in part by D'Arco Silvio Avalle. See Gabriele D'Annunzio, "Dal taccuino inedito dell'Alcyone," Strumenti iritici, Anno VI, n. 18 (June, 1972), 163-169

23 The longer of the two surviving prose sketches for "L'infinito" runs as follows: "Caro luogo a me sempre fosti benché ermo e solitario, e questo verde lauro che gran parte cuopre dell'orizzonte allo sguardo mio. Lunge spingendosi l'occhio gli si apre dinanzi interminato spazio vasto orizzonte per cui si perde l'animo mio nel silenzio infinito delle cose e nella amica quiete par che si riposi se pur spaura. E al rumor d'impetuoso vento e allo stormir delle foglie delle piante a questo tumultuoso fragore l'infinito silenzio paragono," Giacomo Leopardi, Opere, a cura di Sergio Solmi, I (Milano-Napoli, 1956), p. 305. As symptomatic of the poet's concern for logical argument, I would draw attention to the string of circumstantial connectives ("benché," "per cui," "par che," "se pur") and to the appositions of the second and last sentences, all of which are eliminated in the final version, in favor or a far more intuitive and "poetic" syntax. The "verde lauro" was also replaced by the more homely (and so much more snugly Pascolian!) "siepe," almost as if, in this instance at least, Leopardi had anticipated the poet's censure of "l'altro lerrore] del falso, per il quale tutti gli alberi si riducono a faggi, tutti gli uccelli a usignuolo." Giovanni Pascoli, "Il Sabato," in Prose, I (Milano, 1946), p. 59. The trees that were not reduced to "faggi" in the academic arboretum were of course reduced to "lauri," axiomatically "verdi."

$24 \mathrm{I}$ am currently revising an article, "An Errand to Nature: A Reading of Pascoli's Norembre," which discusses in passing the preliminary drafts of this famous lyric, and which I hope will be published later this year by Yale Italian Studies.

25 Giovanni Pascoli, Myricae, a cura di Giuseppe Nava, II, 261. For the sake of clarity, I have omitted a cancelled reading (a singular for a plural) recorded in Nava's diplomatic transcription.

26 ibid., Il, 487. The note, on a loose scrap of paper, is inserted in a copy of the second edition of Myricae in the library of Castelvecchio: "La chiusa è un verso profondamente suggestivo d'Omero. Chi non conosce il mirabile quadro che chiude la rapsodia 20 dell'Iliade? [Here Pascoli cites the Greek text.| Quei cavalli, ritti presso i cocchi, nella grande pianura, con la città nereggiante alle spalle! lo li vedo, e non ho mai veduto cosa cosí bella." The Homeric passage which the poet refers to (VIII, 562-565) is translated by A.T. Murray as follows: "A thousand fires were burning in the plain and by each sat fifty men in the glow of the blazing fire. And their horses, eating of white barley and spelt, stood beside the cars and waited for fair-throned Dawn." Homer, The Iliat, with an English translation by A.T. Murray, Ph.D. (Cambridge, Mass., 1924), I, 381. The date I gave for the fall of Troy is the traditional one mentioned in the Enciclopertin Italiana.

27 Giovanni Pascoli, Myricae, II, 450-451. The word "nero" in the third sentence was subsequently cancelled and "stracci" written in its place. Nava suggests convincingly that "toffus" is Pascoli's spelling of the French "touffus."

28 CP94 is reproduced in a photograph in Vol. 1 of Nava's edition, opposite p. CLXVIII. The recto, in addition to the draft of "L'assiuolo," contains the titles of various sections of the poemetto "La sementa." On the back are the words "brividi, I lagrime, I sussulti di gioia," which appear to refer to the opening sentence of the essay "Il fanciullino": "E' dentro noi un fanciullino che non solo 
ha brividi, come credeva Cebes Tebano che primo in se lo scoperse, ma lagrime ancora e tripudi suoi." Giovanni Pascoli, Prose, I (Milano, 1946), p. 5.

29 Prose, I, 616. There is a fine analysis of "L'assiuolo" and of the implications of this remark of Pascoli's toward the end of Nava's introductory essay. See Giovanni Pascoli, Myricae, I, LXXXVIII-XC. Even before the comment was known, the poem had of course already been treated by Gianfranco Contini as paradigmatic of the qualities that place Pascoli with the French symbolists in the mainstream of the modern lyric.

30 Stéphane Mallarmé, "Sur l'évolution littéraire (Réponse à une enquête de Jules Huret)," CEuvres complètes (Paris, 1945), pp. 868-69. I incline to think that Pascoli's revolution was rather less unaware than the late Giacomo Debenedetti (a critic whose work I greatly admire) would have us believe. See Giacomo Debendetti, Pascoli: Ia rivoluzione inconsapevole (Milano, 1979). As this article was going to print, the first volume of an important new edition of Pascoli's works, edited by my friend Maurizio Perugi, appeared in Italy. It will be followed in early 1981 by a second companion volume and by a number of volumes of Perugi's essays on the poet. See Giovanni Pascoli, Opere, I, (Milano-Napoli, 1980). 